\title{
Second capture of Promops centralis (Chiroptera) in French Guiana after 28 years of mist-netting and description of its echolocation and distress calls
}

\author{
Jérémy S.P. FROIDEVAUX ${ }^{1, a, b, *} \mathbb{0}$, Charlotte ROEMER ${ }^{2,3, a}$, Clément LEMARCHAND ${ }^{4}$, Joan MARTÍ- \\ CARRERAS 5 , Piet MAES 5 , Vincent RUFRAY ${ }^{6,7}$, Quentin URIOT ${ }^{7}$, Sylvain URIOT ${ }^{7}$, Adrià LÓPEZ- \\ BAUCELLS ${ }^{8}$ \\ University of Bristol, School of Biological Sciences, Life Sciences Building, 24 Tyndall Avenue, BS8 1 TQ Bristol, United Kingdom \\ Centre d'Ecologie et des Sciences de la Conservation (CESCO), Muséum national d'Histoire naturelle, Centre National de la Recherche Scientifique, Sorbonne \\ Université, CP 135, 57 rue Cuvier 75005 Paris, France \\ 3 Centre d'Ecologie Fonctionnelle et Evolutive (CEFE), Centre National de la Recherche Scientifique, Université Montpellier, Université Paul Valéry Montpellier 3, EPHE, \\ IRD, Montpellier, France \\ ${ }^{4}$ Les Ecologistes de l'Euzière, Domaine de Restinclières, 34730 Prades-le-lez, France \\ Katholieke Universiteit Leuven, Department of Microbiology and Immunology, Rega Institute, Leuven BE3000, Belgium \\ 6 Biotope Amazonie, 30 Domaine de Montabo, Lotissement Ribal, 97300 Cayenne, France \\ Groupe Chiroptères de Guyane, 15 Cité Massel, 97300 Cayenne, France \\ ${ }^{3}$ Museu de Ciències Naturals de Granollers, Av. Francesc Macià 51, 08402 Granollers, Catalonia, Spain \\ These authors contributed equally to this study \\ b Present address: Centre d'Ecologie et des Sciences de la Conservation (CESCO), Muséum national d'Histoire naturelle, Centre National de la Recherche Scientifique, \\ Sorbonne Université, Concarneau, France \\ * Corresponding author: jeremy.froidevaux@bristol.ac.uk; (1D) https://orcid.org/0000-0001-6850-4879
}

\section{ABSTRACT}

The Amazonian basin harbours some of the most bat-diverse ecosystems worldwide. Yet, information on elusive, high-flying bat species such as Molossidae is scarce or virtually missing in the literature, which hampers conservation efforts both locally and globally. The recent advent of new technologies specifically designed to survey bats, such as passive ultrasound detectors and acoustic lures, has significantly increased understanding of bat ecology and distribution, and has allowed researchers to gather new and valuable information which was impossible to collect in the past. We undertook a rapid bat diversity assessment in French Guiana using acoustic lures to aid in capturing high-flying insectivorous bat species. Here we report the second and third capture record of Promops centralis (Chiroptera, Molossidae) for French Guiana, captured after 28 years since the first and only captures so far in the county. One individual was a post-lactating female and represents the first record of breeding $P$. centralis in French Guiana. We provide (i) morphometric and acoustic data (including the species' distress calls) as well as detail photography to aid in species identification; and (ii) COI and CytB sequences of the two individuals (first mitochondrial sequences for French Guiana).

KEYWORDS: Amazon, bats, bioacoustics, Molossidae, mitochondrial sequences

\section{Segunda captura de Promops centralis (Chiroptera) en la Guayana Francesa después de 28 años de muestreos con redes y descripción de su ecolocalización y sus llamadas de alarma}

\section{RESUMEN}

La cuenca amazónica alberga algunos de los ecosistemas más diversos en fauna quiropterológica del mundo. Sin embargo, en la literatura científica no encontramos información muy detallada sobre especies de murciélago esquivas como las de la família Molossidae. Esta carencia condiciona y obstaculiza los esfuerzos de conservación tanto a escala local como global. El desarrollo reciente de nuevas tecnologías diseñadas específicamente para muestrear quirópteros, como los detectores de ultrasonidos pasivos o los reclamos acústicos mediante el uso de llamadas de alta frecuencia, ha incrementado nuestro conocimiento sobre su ecología y distribución. Además, ha permitido a los investigadores obtener nuevos datos que eran prácticamente imposibles de conseguir en el pasado. Llevamos a cabo una evaluación rápida de diversidad quiropterológica en la Guayana Francesa, utilizando reclamos acústicos con el objetivo de capturar especies insectívoras de vuelo alto. En este estudio, aportamos la segunda y tercera captura de Promops centralis (Chiroptera, Molossidae) para Guayana Francesa después de 28 años desde sus primeras y únicas capturas hasta ahora. Uno de los indivíduos capturados fue una hembra poslactante, el primer registro de reproducción de la especie. Aportamos (i) datos morfométricos, bioacústicos (incluyendo las llamadas de alarma típicas de la especie) y fotografías de detalles para facilitar su identificación; y (ii) las secuencias de COI y CytB de los dos individuos (las primeras secuencias mitocondriales para la Guayana Francesa).

PALABRAS CLAVE: Amazonas, bioacústica, murciélagos, Molossidae, secuencias mitocondriales

CITE AS: Froidevaux, J.S.P.; Roemer, C.; Lemarchand, C.; Martí-Carreras, J.; Maes, P.; Rufray, V.; Uriot, Q.; Uriot, S.; López-Baucells, A. 2020. Second capture of Promops centralis (Chiroptera) in French Guiana after 28 years of mist-netting and description of its echolocation and distress calls. Acta Amazonica 50: 327-334. 


\section{INTRODUCTION}

Harbouring a rich diversity of habitats, including the tropical Amazonian forest, French Guiana represents a hotspot of bat diversity. Currently, 106 bat species from nine families are listed in this county (Catzeflis et al. 2013; Moratelli et al. 2015; Rufray 2015). The advent of new techniques for surveying bats such as the use of bioacoustics is currently pushing forward our understanding of bat ecology and distribution (Britzke et al. 2013; Gibb et al. 2019), allowing the discovery of new species and opening ecological research questions and fields that were entirely inaccessible in the past.

The most common survey technique in bat studies used in the tropics is the ground mist-netting, followed by canopy netting, and direct roost search (MacSwiney et al. 2008). Nevertheless, the use of acoustic studies is increasing in the Neotropics (Barataud et al. 2013) due to the technological advances in new affordable detectors and automatic classifiers (Hill et al. 2019). While mist-netting has been proved to be highly efficient for phyllostomid bats, bioacoustics seem to be more appropriate for aerial insectivorous bats such as molossids or emballonurids (MacSwiney et al. 2008). More recently, the development of ultrasonic acoustic lures to attract bats to the mist-nets has gained momentum amongst bat researchers and naturalists (Quackenbush et al. 2016; Samoray et al. 2019), especially for targeting elusive insectivorous species. Although their effectiveness has been proven in different contexts and for several species (Hill and Greenaway 2005; Lintott $e t$ al. 2013; Quackenbush et al. 2016), acoustic lures have been rarely used in the tropics (Chaverri et al. 2018).

Amongst all bat families that occur in the Neotropics, Molossidae is one of the least known, probably due to the difficulty of capturing molossids using traditional sampling methods (Kalko et al. 2008). These species roost in relatively inaccessible crevices or cavities and forage at high altitudes above forest canopies, in open areas and over aquatic habitats, where mist-netting is either impossible or inefficient (LópezBaucells et al. 2018; Torrent et al. 2018). As a result, natural history data for these species are generally scarce or virtually missing in the literature. Among molossids, the big crested mastiff bat, Promops centralis is one of the most elusive and less studied species (Hintze et al. 2019). As many other molossids, P. centralis seems to be a habitat-opportunist, having been reported in a wide range of environments such as forests, wetlands, deserts, and urban areas (Gregorin and Taddei 2000; Lim and Engstrom 2001; Jung and Kalko 2010, 2011; Fischer et al. 2015; González-Terrazas et al. 2016; Hintze et al. 2019). In terms of echolocation, $P$. centralis is easily recognizable, with alternate concave-convex pairs of pulses produced at -30 and $-35 \mathrm{kHz}$, respectively (López-Baucells et al. 2016; Arias-Aguilar et al. 2018).

We undertook a rapid bat diversity assessment in French Guiana using mist nets and acoustic lures, with the main aim of improving the natural history understanding of molossid bats. Here we report the second and third capture records of P. centralis for French Guiana, captured after 28 years since the first and only captures in the county so far by Simmons and Voss (1998). We present data on the morphology, echolocation (including distress calls), and mitochondrial cytochrome oxidase I (COI) and cytochrome b (CytB) gene sequences of P. centralis from French Guiana.

\section{MATERIAL AND METHODS}

\section{Sampling design}

We performed a total of 14 consecutive nights of bat trapping with mist nets between the 8 and 21 November 2019 at 14 sites (Figure 1; see details in the Supplementary Material, Table S1). At each site, we installed between two and five nets of $12 \mathrm{~m}$ length and $2.5 \mathrm{~m}$ height (Ecotone, Gdynia, Poland), and trapping took place from sunset for four hours. Each survey night, three mist nets were equipped with an acoustic lure (Bat Lure, Apodemus, Wageningen, The Netherlands) broadcasting social and distress calls (see Chaverri et al. 2018) of bats from four different families: Phyllostomidae, Vespertillionidae, Molossidae and Emballonuridae.

\section{Morphological, acoustic and genetic analyses}

Mist nets were checked every $20 \mathrm{~min}$, and bats were removed from the nets as soon as possible. Species were identified using identification keys from López-Baucells et al. (2016) and Charles-Dominique et al. (2001). Information on sex, age (juvenile or adult), reproductive status (not reproductively active, reproductively active, lactating female, or pregnant female), body mass, and forearm length were taken for all captured individuals. Sex and reproductive status were assessed by inspecting genitalia, while age was determined by trans-retro-illuminating wing joints (Anthony 1988). Bat capture and handling were conducted following guidelines approved by the American Society of Mammalogists (Sikes and Gannon 2011). To confirm species identification of individuals with ambiguous morphological criteria, one to two wing punches were taken per individual and were subsequently processed and analysed to obtain mitochondrial genetic classification (hereafter referred as DNA barcoding). When the acoustic repertoire of a species was poorly described in the literature, we recorded echolocation calls while releasing individuals, either during the night if the acoustic activity of free-flying bats was very low, or at sunrise of the same night to avoid the simultaneous presence of other individuals. Different ultrasound microphones were used for the recordings: M500384 (Pettersson, Uppsala, Sweden) and Echo Meter Touch Pro (Wildlife Acoustics, Maynard, USA). Releases were performed in open environments (forest clearings or wide roads). We also recorded distress calls when an individual was handled. Lactating females were always released at night. 


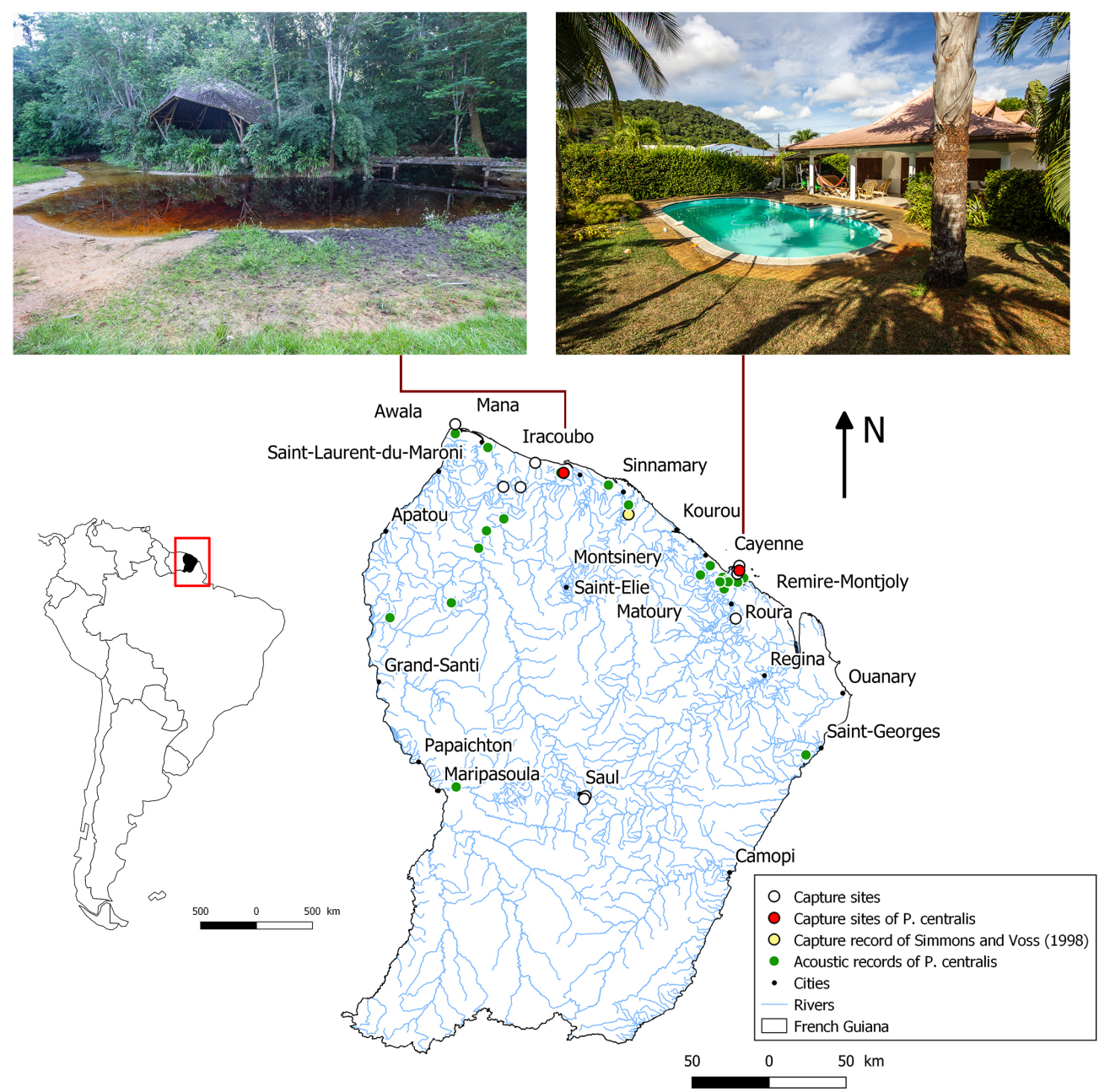

Figure 1. Locations records of Promops centralis in French Guiana (acoustic records and capture sites, including the two new capture locations reported in here). Sampling sites where the species has not been recorded in our study are also shown. Locations of previously known acoustic records have been retrieved from Faune Guyane (www.faune-guyane.fr). Blue lines represent the main river systems. @ Layers: Institut National de I'Information Géographique et Forestière 2017. This figure is in color in the electronic version.

Echolocation and distress calls of the two P. centralis individuals captured were analysed using Kaleidoscope (Wildlife Acoustics, USA) with a 512-Hanning FFT window. For each individual, we measured the frequency of maximum energy of ten good-quality echolocation calls. The first series of pulses recorded during the release were discarded as they were not truly representative calls. Distress calls were only recorded from the male while handled. Measurements such as call duration and frequency of maximum energy of harmonics were conducted on 19 good-quality calls.

Genetic analyses were conducted at the Department of Microbiology and Immunology at KU Leuven (Leuven, Belgium). Mitochondrial DNA from both individuals was extracted from muscular tissue (wing punches) using total nucleic acid extraction with RNAeasy mini kit (Cat No. 74104, Qiagen, USA), following specification from the manufacturer. Both COI and CytB sequences were amplified using One-Step RT-PCR kit (Cat No. 210210, Qiagen, Germany), following specifications from the manufacturer. Primers Molcit-F AATGACATGAAAAATCACCGTTGT and MVZ-16 AAATAGGAARTATCAYTCTGGTTTRAT were used to amplify CytB (Ibáńez et al. 2006) and UTyr 5'-ACCYCTGTCYTTAGATTTACAGTC-3' and C1L705 5'-ACTTCDGGGTGNCCRAARAATCA-3' COI (Hassanin et al. 2012). Thermocycling was conducted as follows: 15 min at $94^{\circ} \mathrm{C}, 30 \mathrm{sec}$ at $94^{\circ} \mathrm{C}, 30 \mathrm{sec}$ at $55^{\circ} \mathrm{C}, 1 \mathrm{~min}$ at 72 ${ }^{\circ} \mathrm{C}$ and $10 \mathrm{~min}$ at $72^{\circ} \mathrm{C}$. Molecules were amplified for 40 cycles (a cycle corresponding to a repetition of the underlined temperatures and times). Amplicons for both individuals were purified using ExoSAP-IT (Cat No. 78201.1, Thermo Fisher Scientific, USA) and sequenced by Sanger sequencing (Macrogen Europe, Meibergdreef, Amsterdam-Zuidoost). Chromatograms were assembled with UGENE v1.31.0 and manually corrected. Sequences are deposited in GenBank as 
follows: MT350796 and MT350797 for the female individual and MT350798 and MT350799 for the male indiviudal (CytB and COI, respectivley).

\section{RESULTS}

We captured 450 individuals belonging to 40 bat species (overall results of the survey are available in www.fauneguyane.fr), including two individuals of Promops centralis. The identification was primarily based on morphological features, and was subsequently confirmed with acoustic and genetic analyses. The first individual was captured on 8 November at 18:25 in a net placed along a swimming pool located in a private garden of Remire-Montjoly (Figure 1). It was a nonreproductively active male with a forearm length of $51.8 \mathrm{~mm}$, for which no other morphological features were measured. It was released at the same location. We captured the second individual on 21 November around 20:20, $131 \mathrm{~km}$ away from the first location, in a net placed over a shallow water body located near a secondary road westward of Iracoubo (Figure 1). This individual was captured in front of a bat lure playing distress and social calls of several molossid species, including distress calls recorded from the first $P$. centralis we captured. The individual was a post-lactating female and therefore represents the first report of breeding $P$. centralis in French Guiana (Figure 2). All the external morphological measurements have been included in Table 1 .

Regarding their echolocation, both individuals presented the typical acoustic features of $P$. centralis, with alternate concave-convex pairs of modulated pulses. When hand-
Table 1. External morphological measurements of the (i) post-lactating female of Promops centralis captured near Iracoubo and (ii) two females captured by Simmons and Voss (1998) near Paracou, French Guiana. Values for the two females are the mean (observed range).

\begin{tabular}{|c|c|c|}
\hline $\begin{array}{l}\text { External morphological } \\
\text { measurement }\end{array}$ & $\begin{array}{l}\text { Present study } \\
\text { (one female) }\end{array}$ & $\begin{array}{l}\text { Simmons and Voss } \\
1998 \text { (two females) }\end{array}$ \\
\hline Body weight (g) & 21.5 & $22.9(22.8-30.0)$ \\
\hline Body length (mm) & 67.2 & - \\
\hline Hindfoot (mm) & 10.3 & $13.0(13.0-13.0)$ \\
\hline Calcar (mm) & 24.9 & - \\
\hline Tail (mm) & 58.4 & $56.0(46.0-66.0)$ \\
\hline Ear length (mm) & 13 & $14.5(14.0-15.0)$ \\
\hline Tragus width (mm) & 4.9 & - \\
\hline Tragus height (mm) & 6.1 & - \\
\hline Forearm (mm) & 51.8 & $52.8(52.0-53.5)$ \\
\hline Thumb (mm) & 4.6 & - \\
\hline Fifth metacarpal bone (mm) & 31.5 & - \\
\hline Fifth phalanx 1 (mm) & 14.7 & - \\
\hline Fifth phalanx $2(\mathrm{~mm})$ & 8.8 & - \\
\hline Fourth metacarpal bone (mm) & 50.5 & - \\
\hline Fourth phalanx 1 (mm) & 20.6 & - \\
\hline Fourth phalanx 2 (mm) & 4.0 & - \\
\hline Third metacarpal bone (mm) & 53.2 & - \\
\hline Third phalanx 1 (mm) & 24.3 & - \\
\hline Third phalanx 2 (mm) & 20.2 & - \\
\hline Third phalanx 3 (mm) & 5.9 & - \\
\hline Second metacarpal bone (mm) & 51.4 & - \\
\hline
\end{tabular}
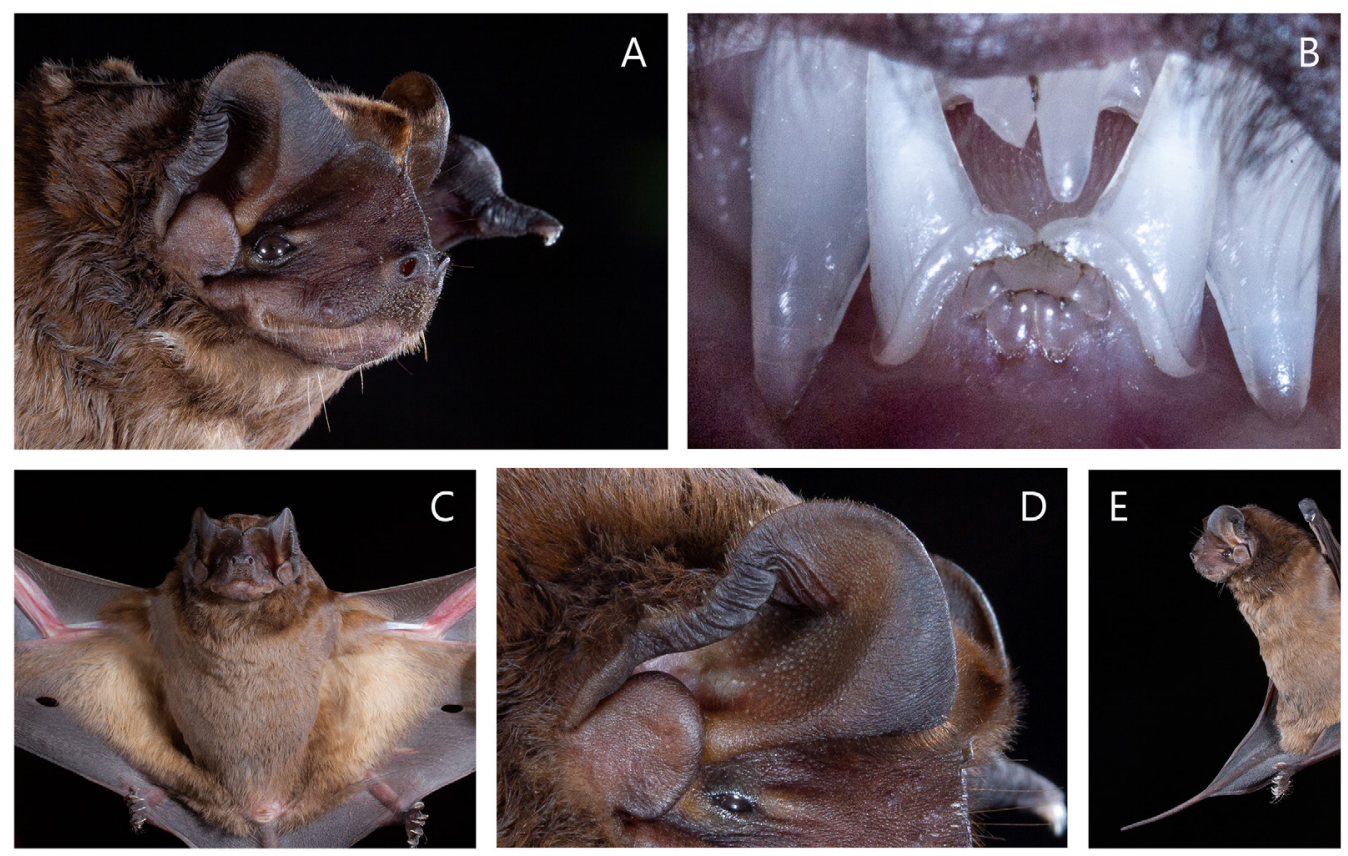

Figure 2. External diagnostic morphological traits of the female Promops centralis. A - strong ridge on the nose; B - 4 lower incissors; $C$ - extended fur across the lower part of the wings; $\mathrm{D}$ - yellowish tone of the skin around the eyes; $\mathrm{E}$ - global aspect of $P$. centralis. This figure is in color in the electronic version. 

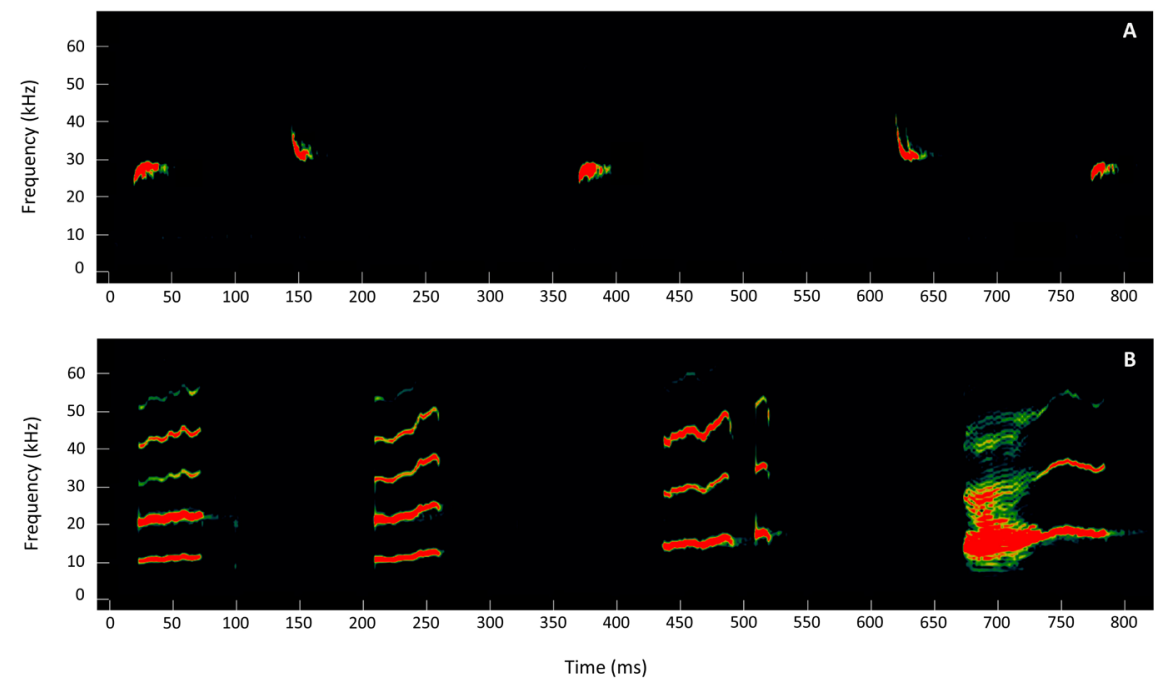

Figure 3. Sonograms of A - echolocation calls recorded when the animals were hand released; and B - most common distress calls recorded while the animal was handled. Sonograms were produced using Kaleidoscope (Wildlife Acoustics, USA) with a 512-Hanning FFT window. This figure is in color in the electronic version.

released, the male and female emitted concave calls with the frequency of maximum energy at $29.2 \mathrm{kHz}$ (range: $27.8-29.8$ ) and $27.4 \mathrm{kHz}(26.9-27.8)$, respectively, and convex calls at $34.3 \mathrm{kHz}(33.1-35.2)$ and $31.7 \mathrm{kHz}$ (31.4-32.2), respectively (Figure 3; available at https://sonotheque.mnhn.fr/sounds/ MNHN/SO/2020-192 and https://sonotheque.mnhn.fr/ sounds/mnhn/so/2020-174). The most common distress calls of $P$. centralis consisted of long frequency-modulated calls (mean \pm SD: $114.5 \pm 52.5 \mathrm{~ms} ; 19$ calls), with several harmonics with mean frequency of maximum energy at 15.8 (SD 2.9), 30.7 (SD 5.5), 44.3 (SD 4.4) and 53.6 (SD 6.2) kHz (Figure 3; sample MNHN-SO-2020-193 available at https:// sonotheque.mnhn.fr/sounds/MNHN/SO/2020-193). These structures are described by Nagel (2006) as tonal calls, more specifically trills (> 3 frequency modulations, with irregular patterns), and could appear noisy.

Reconstruction of both COI and CytB sequences of the two individuals from DNA barcoding yielded in two diagnostic sequences of 655 and 784 nucleotides, respectively. All four sequences were analysed with BLAST (Mega-Blast) (Camacho et al. 2009) using the complete NCBI nucleotide database (accessed on April 2020). All sequences were affiliated to Promops centralis with an average nucleotide identity $>$ 99\% (Table 2). Controversially, the COI sequence from the

Table 2. Summary of taxonomy affiliation of both Promops centralis individuals captured in French Guiana, based on genetic barcoding.

\begin{tabular}{llllll}
\hline Individual Location & Gene & $\begin{array}{l}\text { GenBank } \\
\text { entry }\end{array}$ & $\begin{array}{l}\text { Closest } \\
\text { reference }\end{array}$ & $\begin{array}{l}\text { Identity } \\
\text { percentage }\end{array}$ \\
\hline Male & Remire-Montjoly & COI & MT350799 & JF449067.1 & $99.24 \%$ \\
& & CytB & MT350798 & MH058091.1 & $98.98 \%$ \\
\hline Female & Iracoubo & COI & MT350797 & MH185193.1 & $99.23 \%$ \\
& & CytB & MT350796 & MG029508.1 & $99.11 \%$
\end{tabular}

female individual (GenBank accession number MT350797) had Promops davisoni as one of its closest references (GenBank accession number MH185193.1). Detailed inspection of secondary hits of MT350797 against NCBI Blast database showed comparable identities with Promops centralis. However, the CytB sequence from the same individual (GenBank accession number MT350796) was classified as Promops centralis (closest reference as GenBank accession number MG029508.1). Based on similarity results from CytB and COI sequences, it can be assumed that both individuals belong to the Promops centralis, concording with our previous assessment (Table 2).

\section{DISCUSSION}

Using an integrative approach combining morphological, acoustic and genetic data, we confirmed the presence of Promops centralis in French Guiana, adding the second and third capture records for this county after more than 28 years from the first captures of this species (Simmons and Voss 1998). We captured one male and one post-lactating female in two sites located $131 \mathrm{~km}$ apart and situated $>80$ and $>45$ $\mathrm{km}$ away, respectively, from the site where the first capture of $P$. centralis was made. Our capture records contribute to improve current knowledge of $P$. centralis distribution in French Guiana. At a larger scale, our records fall into the potential but poorly known distribution range of $P$. centralis in South America recently modelled by Hintze et al. (2019).

Mist-net surveys have been intensively conducted in French Guiana since the 1990s, especially by CharlesDominique et al. (2001) and through numerous research projects (e.g. Thoisy et al. 2014; Moratelli et al. 2015; Catzeflis et al. 2016; Lavergne et al. 2016; Filippi-Codaccioni et al. 2018). Yet it was only from 2011, with the advent of 
bioacoustics, that $P$. centralis was registered again using bat detectors (e.g. Barataud et al. 2013). The 25 acoustic records so far suggest that $P$. centralis is well distributed in French Guiana (Figure 1; www.faune-guyane.fr) and present in many habitats, from tropical rainforest to marshes and lowland wetlands. Nevertheless, despite the relatively high capture effort and, more recently, the use of new capture techniques (e.g. canopy nets) the enigmatic and poorly studied $P$. centralis has remained uncaught in French Guiana for nearly three decades.

Our results are of great interest considering the rarity of the mentions of this species in French Guiana and the difficulties of capturing high-flying foragers. It is likely, albeit not evidence-based, that the second $P$. centralis was attracted to the net due to the distress calls of the first individual, that were broadcasted by the acoustic lure. We provide the first recordings of distress calls for this species and make them available on open access, so other researchers can use them in the field. Comprehensive bat call libraries are essential to improve bat sampling efficacy and will probably drive the future of both acoustic and mist-netting bat surveys worldwide (Waters and Gannon 2004; López-Baucells et al. 2019). Further work is needed to confirm whether distress calls of P. centralis indeed attract conspecifics, as observed in other species (Chaverri et al. 2018).

Promops centralis may be more common than previously expected in Central and South America (Hintze et al. 2019), and several factors can explain the lack of records in the literature. Firstly, this species is difficult to capture using ground-nets due to its foraging behaviour. Optimizing net configuration and location may, however, help in increasing the capture rate (Trevelin et al. 2017). In this study, the two individuals of $P$. centralis were captured in nets placed across a shallow water body in open spaces. While high-flying species are adapted to foraging above canopy levels, they descend to drink, and setting mist-nets across water bodies located in open space represents a better option than setting-up nets above the canopy. Besides, few acoustic surveys are conducted in the tropics, especially in the Amazon (MacSwiney et al. 2008; López-Baucells et al. 2016). More information about the species distribution range could easily be gained by deploying more detectors in suitable habitats. Moreover, it is likely that the species is commonly confused by bat researchers and naturalists with other widespread molossid species that present similar morphology, such as Molossus rufus (Simmons and Voss 1998). It is therefore of utmost importance to generate high-quality taxonomic affiliation of unique captures, as was achieved in this study.

\section{CONCLUSIONS}

Our reports of $P$. centralis constitute the most updated information for the species in French Guiana. We present morphological, acoustic, and genetic baseline information that will hopefully optimize the output of future bat research in the Neotropics - including genetic mitochondrial sequences and raw acoustic data - all of them usually scarce in the literature. The lack of genetic and acoustic references still represents an important obstacle that hinders bat research and conservation in the tropics. Further research is needed to understand the potential of acoustic lures to attract and capture elusive, highflying bat species.

\section{ACKNOWLEDGMENTS}

This work was funded by the Direction de l'Environnement, de l'Aménagement et du Logement de la Guyane. We thank Gareth Jones (University of Bristol), the Muséum national d'Histoire naturelle (MNHN), the Natural Science Museum of Granollers, the Ecologistes de l'Euzière, Biotope and the Groupe Chiroptères Languedoc-Roussillon for lending fieldwork material. We also thank Michel Barataud, Adriana Schatton, Robert Ulrich, Katja Nitze, Vanessa Mata, and Francisco Amorim for making social and distress calls of bats available for this research. We are grateful to Audrey Rufray and the Parc Amazonien de Guyane for inviting us and providing essential logistical support, and Arthur Clarke (Office National des Forêts) for additional logistical help. We thank Lia R.V. Gilmour (University of West England) for proofreading the manuscript. The comments of Claudia Keller, Paulo Bobrowiec and two anonymous reviewers greatly helped improving this paper.

\section{REFERENCES}

Anthony, E.L.P. 1988. Age determination in bats. In: Kunz, T.H. (Ed.). Ecological and Behavorial Methods for the Study of Bats, 2nd ed. The John Hopkins University Press, Baltimore, p. 47-58.

Arias-Aguilar, A.; Hintze, F.; Aguiar, L.M.S.; Rufray, V.; Bernard, E.; Pereira, M.J.R. 2018. Who's calling? Acoustic idetification of Brazilian bats. Mammal Research, 63: 231-253.

Barataud, M.; Giosa, S.; Leblanc, F.; Rufray, V.; Disca, T.; Tillon, L.; Delaval, M.; Haquart, A.; Dewynter, M. 2013. Identification et écologie acoustique des chiroptères de Guyane française. Le Rhinolophe, 19: 103-145.

Britzke, E.R.; Gillam, E.H.; Murray, K.L. 2013. Current state of understanding of ultrasonic detectors for the study of bat ecology. Acta Theriologica, 58: 109-117.

Camacho, C.; Coulouris, G.; Avagyan, V.; Ma, N.; Papadopoulos, J.; Bealer, K.; Madden, T.L. 2009. BLAST+: architecture and applications. BMC Bioinformatics, 10: 421. https://doi. org/10.1186/1471-2105-10-421

Catzeflis, F.; Dewynter, M.; Pineau, K. 2013. Liste taxonomique commentée des chiroptères de Guyane. Le Rhinolophe, 19: 89-102.

Catzeflis, F.; Gager, Y.; Ruedi, M.; De Thoisy, B. 2016. The French Guianan endemic Molossus barnesi (Chiroptera: Molossidae) is a junior synonym for M. coibensis. Mammalian Biology, 81: 431-438. 
Charles-Dominique, P.; Brosset, A.; Jouard, S. 2001. Les chauve-souris de Guyane. Muséum National d'Histoire Naturelle, Paris, 176p.

Chaverri, G.; Ancillotto, L.; Russo, D. 2018. Social communication in bats. Biological Reviews, 93: 1938-1954.

Filippi-Codaccioni, O.; Beugin, M.P.; de Vienne, D.M.; Portanier, E.; Fouchet, D.; Kaerle, C.; et al. 2018. Coexistence of two sympatric cryptic bat species in French Guiana: insights from genetic, acoustic and ecological data. Bmc Evolutionary Biology, 18: 175. https://doi.org/10.1186/s12862-018-1289-8

Fischer, E.; Santos, C.F.; Carvalho, L.F.AdC.; Camargo, G.; Cunha, N.Ld.; Silveira, M.; Bordignon, M.O.; Silva, CdL. 2015. Bat fauna of Mato Grosso do Sul, southwestern Brazil. Biota Neotropica, 15: 1-17.

Gibb, R.; Browning, E.; Glover-Kapfer, P.; Jones, K.E. 2019. Emerging opportunities and challenges for passive acoustics in ecological assessment and monitoring. Methods in Ecology and Evolution 10: 169-185.

González-Terrazas, T.P.; Víquez, L.R.; Ibarra-Macías, A.; Ruíz, A.T.; Torres-Knoop, L.; Jung, K.; Tschapka, M.; Medellín, R.A. 2016. New records and range extension of Promops centralis (Chiroptera: Molossidae). Revista Mexicana de Biodiversidad, 87: 1407-1411.

Gregorin, R.; Taddei, V. 2000. New records of Molossus and Promops from Brazil (Chiroptera: Molossidae). Mammalia, 64: 471-476.

Hassanin, A.; Delsuc, F.; Ropiquet, A; Hammer, C.; Jansen van Vuuren, B.; Matthee, C.; et al. 2012. Pattern and timing of diversification of Cetartiodactyla (Mammalia, Laurasiatheria), as revealed by a comprehensive analysis of mitochondrial genomes. Comptes Rendus Biologies, 335: 32-50.

Hill, A.P.; Prince, P.; Snaddon, J.L.; Doncaster, C.P.; Rogers, A. 2019. AudioMoth: A low-cost acoustic device for monitoring biodiversity and the environment. HardwareX, 6: e00073.

Hill, D.A.; Greenaway, F. 2005. Effectiveness of an acoustic lure for surveying bats in British woodlands. Mammal Review, 35: 116-122.

Hintze, F.; Arias-Aguilar, A.; Dias-Silva, L.; Delgado-Jaramillo, M.; Silva, C.R.; Jucá, T.; et al. 2019. Molossid unlimited: extraordinary extension of range and unusual vocalization patterns of the bat, Promops centralis. Journal of Mammalogy, 101: 417-432.

Ibáñez, C.; Garcia-Mudarra, J.L.; Ruedi, M.; Stadelmann, B.; Juste, J. 2006. The Iberian contribution to cryptic diversity in European bats. Acta Chiropterologica, 8: 277-297.

Jung, K.; Kalko, E.K.V. 2010. Where forest meets urbanization: foraging plasticity of aerial insectivorous bats in an anthropogenically altered environment. Journal of Mammalogy, 91: 144-153.

Jung, K.; Kalko, E.K.V. 2011. Adaptability and vulnerability of high flying Neotropical aerial insectivorous bats to urbanization. Diversity and Distributions, 17: 262-274.

Kalko, E.K.V.; Estrada Villegas, S.; Schmidt, M.; Wegmann, M.; Meyer, C.F. 2008. Flying high - assessing the use of the aerosphere by bats. Integrative and Comparative Biology, 48: 60-73.
Lavergne, A.; Darcissac, E.; Bourhy, H.; Tirera, S.; de Thoisy, B..; Lacoste, V. 2016. Complete genome sequence of a vampire bat rabies virus from French Guiana. Genome Announcements 4: e00188-16.

Lim, B.; Engstrom, M. 2001. Species diversity of bats (Mammalia: Chiroptera) in Iwokrama Forest, Guyana, and the Guianan subregion: implications for conservation. Biodiversity and Conservation, 10: 613-657.

Lintott, P.R.; Fuentes-Montemayor, E.; Goulson, D.; Park, K.J. 2013. Testing the effectiveness of surveying techniques in determining bat community composition within woodland. Wildlife Research, 40: 675-684.

López-Baucells, A.; Rocha, R.; Bobrowiec, P.E.D.; Bernard, E.; Palmeirim, J.M.; Meyer, C.F.J. 2016. Field Guide to Amazonian Bats. Editora INPA, Manaus, 173p.

López-Baucells, A.; Rocha, R.; Da Cunha Tavares, V.; Martins Moras, L.; Silva, S.E.; J.M.; Bobrowiec, P.E.D.; Meyer, C.F.J. 2018. Molecular, morphological and acoustic identification of Eumops maurus and Eumops hansae (Chiroptera: Molossidae) with new reports from Central Amazonia . Tropical Zoology, 31: 1-20.

López-Baucells, A.; Torrent, L.; Rocha, R.; Bobrowiec, P.E.D.; Palmeirim, J.M.; Meyer, C.F.J. 2019. Stronger together: combining automated classifiers with manual post-validation optimizes the workload vs reliability trade-off of species identification in bat acoustic surveys. Ecological Informatics, 49: 45-53

MacSwiney, G.C.; Clarke, F.M.; Racey, P.A. 2008. What you see is not what you get: the role of ultrasonic detectors in increasing inventory completeness in Neotropical bat assemblages. Journal of Applied Ecology, 45: 1364-1371.

Moratelli, R.; Dewynter, M.; Delaval, M.; Catzeflis, F.; Ruedi, M. 2015. First record of Myotis albescens (Chiroptera, Vespertilionidae) in French Guiana. Biodiversity Data Journal, 3: e5314.

Nagel, J.J. 2006. Variation in Distress Calls of New World Bats. Master's thesis, University of Western Ontario, Canada.

Quackenbush, H.; D’Acunto, L.E.; Flaherty, E.A.; Zollner, P.A. 2016. Testing the efficacy of an acoustic lure on bat mist-netting success in North American central hardwood forests. Journal of Mammalogy, 97: 1617-1622.

Rufray, V. 2015. First records of Molossops neglectus and Promops nasutus (Molossidae) in French Guiana. Le Vespère, 5: 349-356.

Samoray, S.T.; Gumbert, M.W.; Roby, P.L.; Janos, G.A.; Borthwick, R.R. 2019. Effectiveness of acoustic lures for increasing indiana bat captures in mist-nets. Journal of Fish and Wildlife Management, 10: 206-212.

Sikes, R.S.; Gannon, W.L. 2011. Guidelines of the American Society of Mammalogists for the use of wild mammals in research. Journal of Mammalogy 92: 235-253.

Simmons, N.B.; Voss, R.S. 1998. The mammals of Paracou, French Guiana: A Neotropical lowland rainforest fauna. Part 1. Bats. Bulletin of the American Museum of Natural History, 237: 1-219.

Thoisy, B.D.; Pavan, A.C.; Delaval, M.; Lavergne, A.; Luglia, T.; Pineau, K.; Ruedi, M.; Rufray, V.; Catzeflis, F. 2014. Cryptic diversity in common mustached bats Pteronotus cf. parnellii 
(Mormoopidae) in French Guiana and Brazilian Amapa. Acta Chiropterologica, 16: 1-13.

Torrent, L.; López-Baucells, A.; Rocha, R.; Bobrowiec, P.E.D.; Meyer, C.F.J. 2018. The importance of lakes for bat conservation in Amazonian rainforests: an assessment using autonomous recorders. Remote Sensing in Ecology and Conservation, 4: 339351.

Trevelin, L.C.; Novaes, R.L.; Colas-Rosas, P.F.; Benathar, T.C.; Peres, C.A. 2017. Enhancing sampling design in mist-net bat surveys by accounting for sample size optimization. PLoS ONE 12: $\mathrm{e} 0174067$.

Waters, D.A.; Gannon, W.L. 2004. Bat call libraries: management and potential use. In: Brigham, R.M.; Kalko, E.; Jones, G.; Parsons, S.; Limpens, H.J.G.A. (Ed.). Bat Echolocation Research: Tools, Techniques, and Analysis. Bat Conservation International, Austin, p.150-157.

RECEIVED: $23 / 04 / 2020$

ACCEPTED: 01/08/2020

ASSOCIATE EDITOR: Paulo D. Bobrowiec 
SUPPLEMENTARY MATERIAL (only available in the electronic version)

Froidevaux et al. Second capture of Promops centralis (Chiroptera) in French Guiana after 28 years of mist-netting and description of its echolocation and distress calls

Table S1. Information on the mist net survey for a rapid bat diversity assessment conducted in French Guyana (France) in November 2019. NA = data not available.

\begin{tabular}{|c|c|c|c|c|c|c|c|}
\hline Date & Location & Observers & Mistnet & Coordinate_X & Coordinate_Y & $\begin{array}{l}\text { Habitat__ } \\
\text { category }\end{array}$ & Habitat_details \\
\hline 20191108 & Private Garden, Cayenne & $\mathrm{JF} / \mathrm{ALB} / \mathrm{CL} / \mathrm{CR} / \mathrm{VR}$ & 1 & -52.2782783 & 4.9231093 & Garden & Garden; under mango tree \\
\hline 20191108 & Private Garden, Cayenne & $\mathrm{JF} / \mathrm{ALB} / \mathrm{CL} / \mathrm{CR} / \mathrm{VR}$ & 2 & -52.2784071 & 4.9230387 & Garden & Garden; open \\
\hline 20191108 & Private Garden, Cayenne & $\mathrm{JF} / \mathrm{ALB} / \mathrm{CL} / \mathrm{CR} / \mathrm{VR}$ & 3 & -52.2780916 & 4.9228976 & Garden & $\begin{array}{l}\text { Garden; next to swimming } \\
\text { pool }\end{array}$ \\
\hline 20191109 & Water treatment plant, Cayenne & $\mathrm{JF} / \mathrm{ALB} / \mathrm{CL} / \mathrm{CR} / \mathrm{VR}$ & 1 & -52.3319610 & 4.9254240 & Open & Swamp; open \\
\hline 20191109 & Water treatment plant, Cayenne & $\mathrm{JF} / \mathrm{ALB} / \mathrm{CL} / \mathrm{CR} / \mathrm{VR}$ & 2 & -52.3330810 & 4.9261300 & Forest edge & $\begin{array}{l}\text { Perpendicular to mangrove } \\
\text { edge }\end{array}$ \\
\hline 20191109 & Water treatment plant, Cayenne & $\mathrm{JF} / \mathrm{ALB} / \mathrm{CL} / \mathrm{CR} / \mathrm{VR}$ & 3 & -52.3332470 & 4.9262810 & Forest & In tall mangrove \\
\hline 20191109 & Water treatment plant, Cayenne & $\mathrm{JF} / \mathrm{ALB} / \mathrm{CL} / \mathrm{CR} / \mathrm{VR}$ & 4 & -52.3334160 & 4.9264390 & Forest & In tall mangrove \\
\hline 20191110 & Kanawa near Carbet, Saül & $\mathrm{JF} / \mathrm{ALB} / \mathrm{CL} / \mathrm{CR}$ & 1 & -53.1745750 & 3.6088510 & Forest & In forest on path \\
\hline 20191110 & Kanawa near Carbet, Saül & $\mathrm{JF} / \mathrm{ALB} / \mathrm{CL} / \mathrm{CR}$ & 2 & -53.1742590 & 3.6085980 & River in forest & Crossing river in forest \\
\hline 20191110 & Kanawa near Carbet, Saül & $\mathrm{JF} / \mathrm{ALB} / \mathrm{CL} / \mathrm{CR}$ & 3 & -53.1743290 & 3.6080530 & Forest & In forest on path \\
\hline 20191111 & Kanawa near Carbet 2, Saül & $\mathrm{JF} / \mathrm{ALB} / \mathrm{CL} / \mathrm{CR} / \mathrm{VR}$ & 1 & -53.1746890 & 3.6094090 & River in forest & Crossing river in open \\
\hline 20191111 & Kanawa near Carbet 2, Saül & $\mathrm{JF} / \mathrm{ALB} / \mathrm{CL} / \mathrm{CR} / \mathrm{VR}$ & 2 & -53.1750000 & 3.6110000 & Forest & In forest on path \\
\hline 20191111 & Kanawa near Carbet 2, Saül & $\mathrm{JF} / \mathrm{ALB} / \mathrm{CL} / \mathrm{CR} / \mathrm{VR}$ & 3 & -53.1749000 & 3.6092900 & Garden & Garden \\
\hline 20191111 & Kanawa near Carbet 2, Saül & $\mathrm{JF} / \mathrm{ALB} / \mathrm{CL} / \mathrm{CR} / \mathrm{VR}$ & 4 & -53.1749000 & 3.6092900 & Garden & Garden \\
\hline 20191111 & Kanawa near Carbet 2, Saül & $\mathrm{JF} / \mathrm{ALB} / \mathrm{CL} / \mathrm{CR} / \mathrm{VR}$ & 5 & NA & NA & Forest & $4 \times 12 \mathrm{~m}$ in forest on path \\
\hline 20191112 & Popotte, Saül & $\mathrm{JF} / \mathrm{ALB} / \mathrm{CL} / \mathrm{CR} / \mathrm{VR}$ & 1 & -53.1745360 & 3.6116950 & River in open & Crossing river in open \\
\hline 20191112 & Popotte, Saül & $\mathrm{JF} / \mathrm{ALB} / \mathrm{CL} / \mathrm{CR} / \mathrm{VR}$ & 3 & -53.1745970 & 3.6113800 & River in open & Crossing river in open \\
\hline 20191112 & Popotte, Saül & $\mathrm{JF} / \mathrm{ALB} / \mathrm{CL} / \mathrm{CR} / \mathrm{VR}$ & 4 & -53.1751950 & 3.6125180 & Forest & In forest \\
\hline 20191112 & Popotte, Saül & $\mathrm{JF} / \mathrm{ALB} / \mathrm{CL} / \mathrm{CR} / \mathrm{VR}$ & 5 & NA & NA & Forest & $4 \times 12 \mathrm{~m}$ in forest on path \\
\hline 20191113 & Roche Bateau, Saül & $\mathrm{JF} / \mathrm{ALB} / \mathrm{CL} / \mathrm{CR}$ & 1 & -53.1848030 & 3.5948040 & Forest & In forest on path \\
\hline 20191113 & Roche Bateau, Saül & $\mathrm{JF} / \mathrm{ALB} / \mathrm{CL} / \mathrm{CR}$ & 2 & -53.1833880 & 3.5941970 & Forest & In forest on path \\
\hline 20191113 & Roche Bateau, Saül & $\mathrm{JF} / \mathrm{ALB} / \mathrm{CL} / \mathrm{CR}$ & 3 & -53.1841580 & 3.5948090 & Riverbank & Riverbank; parallel to river \\
\hline 20191113 & Roche Bateau, Saül & $\mathrm{JF} / A L B / C L / C R$ & 4 & -53.1842110 & 3.5948200 & River in forest & $\begin{array}{l}\text { Crossing river in semi-open } \\
\text { forest }\end{array}$ \\
\hline 20191113 & Roche Bateau, Saül & $\mathrm{JF} / A L B / C L / C R$ & 5 & -53.1841580 & 3.5948090 & Riverbank & $\begin{array}{l}\text { In forest on path; parallel } \\
\text { to river }\end{array}$ \\
\hline 20191114 & Angouleme, Mana & $\mathrm{JF} / \mathrm{ALB} / \mathrm{CL} / \mathrm{CR}$ & 1 & -53.6563085 & 5.4104042 & Riverbank & Riverside; parallel to river \\
\hline 20191114 & Angouleme, Mana & $\mathrm{JF} / \mathrm{ALB} / \mathrm{CL} / \mathrm{CR}$ & 2 & -53.6553510 & 5.4110030 & Garden & Garden \\
\hline 20191115 & Organabo & $\mathrm{JF} / \mathrm{ALB} / \mathrm{CL} / \mathrm{CR}$ & 1 & -53.4680118 & 5.5512150 & River in open & River bridge; crossing river \\
\hline 20191115 & Organabo & $\mathrm{JF} / A L B / C L / C R$ & 2 & -53.4676906 & 5.5519449 & Forest & In forest on path \\
\hline 20191115 & Organabo & $\mathrm{JF} / \mathrm{ALB} / \mathrm{CL} / \mathrm{CR}$ & 3 & -53.4673274 & 5.5534811 & Forest & In forest on path \\
\hline
\end{tabular}


Table S1. Continued.

\begin{tabular}{|c|c|c|c|c|c|c|c|}
\hline Date & Location & Observers & Mistnet & Coordinate_X & Coordinate_Y & $\begin{array}{l}\text { Habitat__ } \\
\text { category }\end{array}$ & Habitat_details \\
\hline 20191116 & Carbet ONF, Montagne de fer & $\mathrm{JF} / \mathrm{ALB} / \mathrm{CL} / \mathrm{CR} / \mathrm{SU} / \mathrm{QU}$ & 1 & -53.5549430 & 5.4071570 & River in open & River bridge; crossing river \\
\hline 20191116 & Carbet ONF, Montagne de fer & $\mathrm{JF} / \mathrm{ALB} / \mathrm{CL} / \mathrm{CR} / \mathrm{SU} / \mathrm{QU}$ & 2 & -53.5559580 & 5.4065390 & Open & $\begin{array}{l}\text { In the middle of forest } \\
\text { clearing }\end{array}$ \\
\hline 20191116 & Carbet ONF, Montagne de fer & $\mathrm{JF} / \mathrm{ALB} / \mathrm{CL} / \mathrm{CR} / \mathrm{SU} / \mathrm{QU}$ & 3 & -53.5546840 & 5.4083870 & Riverbank & Riparian forest \\
\hline 20191116 & Carbet ONF, Montagne de fer & $\mathrm{JF} / \mathrm{ALB} / \mathrm{CL} / \mathrm{CR} / \mathrm{SU} / \mathrm{QU}$ & 4 & -53.5547280 & 5.4079500 & Forest & In forest on path \\
\hline 20191116 & Carbet ONF, Montagne de fer & $\mathrm{JF} / \mathrm{ALB} / \mathrm{CL} / \mathrm{CR} / \mathrm{SU} / \mathrm{QU}$ & 7 & -53.5545890 & 5.4075440 & River in open & Crossing river in open \\
\hline 20191116 & Carbet ONF, Montagne de fer & $\mathrm{JF} / \mathrm{ALB} / \mathrm{CL} / \mathrm{CR} / \mathrm{SU} / \mathrm{QU}$ & 8 & -53.5562840 & 5.4059670 & Forest road & Crossing forest road \\
\hline 20191117 & Croassroad, Montagne de fer & $\mathrm{JF} / \mathrm{ALB} / \mathrm{CL} / \mathrm{CR}$ & 1 & -53.5591880 & 5.4008630 & Forest road & Forest road \\
\hline 20191117 & Croassroad, Montagne de fer & $\mathrm{JF} / \mathrm{ALB} / \mathrm{CL} / \mathrm{CR}$ & 2 & -53.5600350 & 5.4006520 & Forest road & Forest road \\
\hline 20191117 & Croassroad, Montagne de fer & $\mathrm{JF} / \mathrm{ALB} / \mathrm{CL} / \mathrm{CR}$ & 3 & -53.5601260 & 5.4002990 & Forest & In forest \\
\hline 20191117 & Croassroad, Montagne de fer & $\mathrm{JF} / A L B / C L / C R$ & 4 & -53.5598050 & 5.3999430 & Forest road & Forest road \\
\hline 20191117 & Croassroad, Montagne de fer & $\mathrm{JF} / \mathrm{ALB} / \mathrm{CL} / \mathrm{CR}$ & 5 & -53.5614750 & 5.4018220 & Forest road & Forest road \\
\hline 20191118 & Angouleme River, Mana & $\mathrm{JF} / \mathrm{ALB} / \mathrm{CL} / \mathrm{CR} / \mathrm{SU} / \mathrm{QU}$ & 1 & -53.6553816 & 5.4106978 & Garden & Garden \\
\hline 20191118 & Angouleme River, Mana & $\mathrm{JF} / \mathrm{ALB} / \mathrm{CL} / \mathrm{CR} / \mathrm{SU} / \mathrm{QU}$ & 2 & -53.6562313 & 5.4100057 & River in open & Crossing part of large river \\
\hline 20191118 & Angouleme River, Mana & $\mathrm{JF} / \mathrm{ALB} / \mathrm{CL} / \mathrm{CR} / \mathrm{SU} / \mathrm{QU}$ & 3 & -53.6557748 & 5.4098170 & Garden & Garden \\
\hline 20191118 & Angouleme River, Mana & $\mathrm{JF} / \mathrm{ALB} / \mathrm{CL} / \mathrm{CR} / \mathrm{SU} / \mathrm{QU}$ & 4 & -53.6549111 & 5.4101595 & River in forest & $\begin{array}{l}\text { Crossing small river under } \\
\text { tall tree }\end{array}$ \\
\hline 20191118 & Angouleme River, Mana & $\mathrm{JF} / \mathrm{ALB} / \mathrm{CL} / \mathrm{CR} / \mathrm{SU} / \mathrm{QU}$ & 5 & -53.6563717 & 5.4104462 & Riverbank & $\begin{array}{l}\text { Riverside; parallel to river } \\
(6 \times 12 \mathrm{~m})\end{array}$ \\
\hline 20191119 & Reserve de Mana, Mana & $\mathrm{JF} / \mathrm{ALB} / \mathrm{CL} / \mathrm{CR} / \mathrm{SU} / \mathrm{QU}$ & 1 & -53.9354050 & 5.7458750 & Forest & In forest on path \\
\hline 20191119 & Reserve de Mana, Mana & $\mathrm{JF} / \mathrm{ALB} / \mathrm{CL} / \mathrm{CR} / \mathrm{SU} / \mathrm{QU}$ & 2 & -53.9350420 & 5.7460210 & Forest & In forest on path \\
\hline 20191119 & Reserve de Mana, Mana & $\mathrm{JF} / \mathrm{ALB} / \mathrm{CL} / \mathrm{CR} / \mathrm{SU} / \mathrm{QU}$ & 3 & -53.9356790 & 5.7462540 & Forest edge & $\begin{array}{l}\text { Crossing large corridor } \\
\text { parallel to coast }\end{array}$ \\
\hline 20191119 & Reserve de Mana, Mana & $\mathrm{JF} / \mathrm{ALB} / \mathrm{CL} / \mathrm{CR} / \mathrm{SU} / \mathrm{QU}$ & 4 & -53.9354380 & 5.7453360 & Garden & $\begin{array}{l}\text { Next to building with } \\
\text { Molossids roost }\end{array}$ \\
\hline 20191120 & Crique Morpio & $\mathrm{JF} / \mathrm{ALB} / \mathrm{CL} / \mathrm{CR} / \mathrm{QU}$ & 1 & -53.3041920 & 5.4902290 & Open & $\begin{array}{l}\text { In the middle of forest } \\
\text { clearing }\end{array}$ \\
\hline 20191120 & Crique Morpio & $\mathrm{JF} / \mathrm{ALB} / \mathrm{CL} / \mathrm{CR} / \mathrm{QU}$ & 2 & -53.3037110 & 5.4898580 & Riverbank & Riverbank; parallel to river \\
\hline 20191120 & Crique Morpio & $\mathrm{JF} / \mathrm{ALB} / \mathrm{CL} / \mathrm{CR} / \mathrm{QU}$ & 3 & -53.3037250 & 5.4902270 & River in open & Crossing river in open \\
\hline 20191120 & Crique Morpio & $\mathrm{JF} / \mathrm{ALB} / \mathrm{CL} / \mathrm{CR} / \mathrm{QU}$ & 4 & -53.3034570 & 5.4904250 & River in open & Crossing river in open \\
\hline 20191121 & Montagne de Kaw & $\mathrm{JF} / \mathrm{ALB} / \mathrm{CL} / \mathrm{CR} / \mathrm{SU} / \mathrm{QU}$ & 1 & -52.2996980 & 4.6439390 & Open & Open \\
\hline 20191121 & Montagne de Kaw & $\mathrm{JF} / \mathrm{ALB} / \mathrm{CL} / \mathrm{CR} / \mathrm{SU} / \mathrm{QU}$ & 2 & -52.2995390 & 4.6436640 & Forest road & Semi-open path \\
\hline 20191121 & Montagne de Kaw & $\mathrm{JF} / \mathrm{ALB} / \mathrm{CL} / \mathrm{CR} / \mathrm{SU} / \mathrm{QU}$ & 3 & -52.2997970 & 4.6435020 & Forest road & Semi-open path \\
\hline 20191121 & Montagne de Kaw & $\mathrm{JF} / \mathrm{ALB} / \mathrm{CL} / \mathrm{CR} / \mathrm{SU} / \mathrm{QU}$ & 4 & -52.2992010 & 4.6436660 & River in forest & Crossing a pond \\
\hline
\end{tabular}

